\title{
A Palaeopathological Assessment of the Late 19th and Early 20th Century Khoesan
}

\author{
D. BOTHA ${ }^{a} *$ AND M. STEYN ${ }^{a}$
}

\author{
${ }^{a}$ Forensic Anthropology Research Centre, Department of Anatomy, University of Pretoria, Pretoria, South Africa \\ *Correspondence to: Deona Botha, Department of Anatomy, Private BagX323, Arcadia, 0007, South Africa. \\ e-mail: deona.botha@up.ac.za
}

\begin{abstract}
Since the arrival of Dutch colonists in the Cape of Good Hope, South Africa, Khoesan populations were subjected to severe political and economic marginalisation and often fell prey to racial conflict. These circumstances persisted until the early 20th century, during which an astonishing number of Khoesan skeletons were transported from South Africa to various locations in Europe, as at the time, different institutions competed to obtain these remains. The purpose of this study was to assess the health status of the late 19th and early 20th century Khoesan. Skeletal remains housed in two different European institutions were studied. The sample comprised 140 specimens from the Rudolf Pöch Skeletal Collection in Vienna, Austria, and 15 specimens from the Musée de l'Homme in Paris, France. These individuals represent both sexes and were aged between newborn and 75 years, with 54 being younger than 20 years of age. Results indicated high levels of typical disease conditions associated with groups under stress, such as periostitis, cribra orbitalia and porotic hyperostosis. Treponemal disease, rickets, osteoarthritis and trauma were also encountered amongst other more specific indicators of health and disease. This study provided additional knowledge on the health status and lives of the Khoesan people during this turbulent period and created new awareness regarding a group of severely mistreated individuals.
\end{abstract}

\section{Introduction}

This study is based on the hunter-gatherers (San) and pastoralists (Khoikhoi) of southern Africa, otherwise known as the Bushmen and Hottentots. The arrival of European colonists in the Cape of Good Hope from the late 17th century onwards severely undermined the social structure of indigenous San and Khoikhoi populations as they were forced to either retreat to the north (Penn, 2005), settle as farm workers (Smith et al., 2000; Mountain, 2003) or incorporate themselves into existing groups of a different culture such as the Xhosa (Smith et al., 2000). Such circumstances contributed to San and Khoikhoi groups experiencing a disruption in their social organisation, lifestyle, diet and general health status. As a result of this, cultural evolution took place that caused an overlap in lifestyle of San and Khoikhoi 
groups, which appeared to have distorted the boundaries between the two groups. After about two centuries of such marginalisation, many groups and/or individuals were described as Khoesan, with no reference being made to their original lifestyle or standard of living (Inskeep, 1978; Boonzaier et al., 1996; Smith et al., 2000; Penn, 2005).

Tobias (1959) classified surviving Khoesan individuals into five categories. These categories describe the transitional state of the Khoesan as it most likely existed during the colonial contact phase until the early 20th century. These groups include the following: (a) individuals that had remained hunter-gatherers and had little or no contact with agricultural ways (such groups/individuals were, however, very scarce, and the remaining numbers were declining rapidly even in 1959); (b) individuals born in the veldt who came in contact with farms or boreholes to obtain food or water during the dry season but primarily lived in the veldt; (c) individuals born in the veldt who had taken up residence on farms, although they often ventured back to the veldt to hunt and collect food; (d) individuals who were born in the veldt but then moved to farms and never returned to the veldt to obtain resources; and (e) the new generation of Khoesan that was born on farms and was unfamiliar with a lifestyle of hunting and gathering.

At the end of the 19th century and beginning of the 20th century, hardly any Khoesan groups existed independently within the Cape Colony and they were subjected to poverty, declining health and limited nutritional resources as a result of social and political marginalisation. During this time, Khoesan skeletal remains and anthropological materials were perceived to be very valuable by several institutions, not only because of their declining population numbers (Silberbauer, 1965; Smith et al., 2000) but also because of their very unique physical characteristics such as steatopygia (protruding buttocks).

Retrieval of skeletons soon became a profitable endeavour amongst opportunists and curators, both locally and internationally (Legassick \& Rassool, 2000; Botha \& Steyn, 2013). Legassick \& Rassool (2000) describe the unethical manner in which Khoesan skeletons became a lucrative trade during the early 1900s. At the time, the export of Khoesan skeletal material was neither supported nor stopped by the government, as no law was in place preventing illegal trafficking of human remains. The fragile state of Khoesan societies made them exceptionally vulnerable, especially in regard to opportunistic excavation and collection of skeletal remains. This eventually led to the formation of numerous Khoesan skeletal collections in South Africa and Europe (Botha \& Steyn, 2013; Morris \& Scholtz, 2013). Botha \& Steyn (2013) describe the state as well as content of two of these collections in Europe, i.e. the Rudolf Pöch collection (Vienna, Austria) and the Musée de I'Homme collection (Paris, France). The University of Vienna currently houses the largest Khoesan skeletal collection (Rudolf Pöch collection) outside of South Africa.

Several studies have been conducted on the health of modern (20th century), protohistoric (remains from the time period between prehistoric and historic eras) and Holocene Khoesan individuals/groups (prehistoric) in South Africa (Truswell \& Hansen, 1976; Lee, 1979; Tanaka, 1980; Cohen, 1989; Morris, 1992; Pfeiffer \& Crowder, 2004; Pfeiffer, 2007), but no data have yet been issued on the health of the Khoesan as they existed during the late 19th century and early 20th century (historic time period). 
In general, hunter-gatherer groups seemed to be in good health (Tanaka, 1980; Larsen, 2000). However, the health of Khoesan individuals living an agricultural lifestyle (i.e. working on colonial farms) have been reported to be poorer than that of hunter-gatherers, with infectious diseases such as tuberculosis and treponematosis being common (Truswell \& Hansen, 1976; Morris, 1992). Hunting accidents (as encountered in hunter-gatherers) as well as work injuries and interpersonal violence (mostly seen in Khoesan individuals working on farms) contributed to trauma seen in living Khoesan groups (Truswell \& Hansen, 1976; Tanaka, 1980; Walker, 2001; Ortner, 2003; Pfeiffer, 2007).

Marginalisation of this group most likely reached a peak at the end of the 19th century and start of the 20th century, as skeletal collection processes were actively taking place. Khoesan skeletons housed in European collections were amassed from various communities and locations throughout southern Africa, which implies that these individuals may have been from any one of the five categories described by Tobias (1959). Although these skeletons do not represent a specific breeding population, they represent a group at the height of their marginalisation and the era where many traditional communities ceased to exist. The aim of this study was to document the presence of pathological lesions on Khoesan skeletal material collected during the late 19th and early 20th century and to interpret their health status at the time.

\section{Materials and methods}

Two skeletal collections were selected for the purpose of this study: the Rudolf Pöch Skeletal Collection housed at the University of Vienna's Institute for Biology and the Musée de l'Homme Skeletal Collection in Paris, France. The skeletons constituting these two collections were collected from various places in southern Africa, including the Western Cape, Northern Cape, Eastern Cape, Botswana and Namibia (Botha \& Steyn, 2013). Although very few historical records exist regarding the remains of these two collections, one reference is worth mentioning. Pacher (1961) gives a description of the skeletons in the Rudolf Pöch collection with regards to accession numbers, sex and age, i.e. juvenile or adult. This catalogue was used as a general reference while investigating the remains.

A total of 155 skeletons were analysed, which included 140 individuals from the Rudolf Pöch Collection and 15 individuals from the Musée de l'Homme Collection. Preservation of the skeletal material varied from excellent to poor and fragmentary, with most of the material preserved fairly well. In total, the sample contained 31 complete skeletons, 92 incomplete skeletons (one or more major skeletal element missing) and 39 crania.

Age and sex estimates were performed using standard anthropological techniques (Buikstra \& Ubelaker, 1994; Işcan \& Steyn, 2013). Both morphological and metric analyses were employed, and where possible, South African standards were utilised (e.g. Steyn \& Işcan, 1999; Asala, 2001; Patriquin et al., 2003). The age distribution for the complete sample was standardised by following the guidelines provided by Falys \& Lewis (2011). No attempts were made to do a formal palaeodemographic analysis, as these are collections of single individuals rather than a specific breeding population. 
All skeletal elements were examined for the presence of pathological lesions. All conditions were assessed on a macroscopic level on the basis of methods described by Steinbock (1976), Roberts \& Manchester (1995), Aufderheide \& Rodríguez-Martín (1998), Ortner (2003) and Mann \& Hunt (2005). For the assessment of infectious diseases, additional references were used. Literature related to treponemal disease included Hackett (1975, 1976), Rothschild \& Rothschild (1996) and Mays \& colleagues (2003). For the investigation of tuberculosis, Roberts \& Buikstra (2003), Ortner (2008) and Murphy \& colleagues (2009) were included. In some cases, a differential diagnosis was established as it is often difficult to determine the exact cause of the lesion(s) when dealing with skeletal remains.

The presence of cribra orbitalia (CO) and porotic hyperostosis (PH) was scored macroscopically in terms of status, i.e. active or remodelled. Active lesions typically display sharp margins that are clearly defined. Microporosities may be present. Remodelled lesions have a smooth appearance and may lack microporosity, as new bone formation will obliterate peripheral pores (Mensforth et al., 1978; Mittler \& Van Gerven, 1994).

Fractures were classified as antemortem, perimortem or postmortem. Antemortem fractures are usually easily distinguished from perimortem or post mortem fractures on evidence of healing (Sauer, 1998). Within days of a fracture occurring, evidence that suggests healing may be observed. Healed bone often shows callus formation and osteoblastic activity where the fracture took place. There are, however, several problems that may cause fractures to heal incompletely and create a healed state that may easily fracture again. These problems include delayed healing, pseudoarthrosis, poor alignment, bone shortening, osteomyelitis, necrosis of bone and articular changes (Aufderheide \& Rodríguez-Martín, 1998).

It is often difficult to distinguish between perimortem and post mortem fractures as neither display new bone formation. Perimortem fractures usually show no colour differences between the bone area where the fracture occurred and the area surrounding the fracture, i.e. the bone appears as one colour on the fracture edges, surface and surrounding bone (Ubelaker \& Adams, 1995). Fresh bone is more likely to splinter, instead of breaking into small pieces. This occurs because of the collagen in fresh bone that increases the bone's tensile strength. Dry bone, on the other hand, tends to break into a few smaller pieces as it is much more brittle than fresh bone (Sauer, 1998).

Results were compared with documented data on other South African skeletal populations using chi-squared analyses. These included Riet River and Kakamas samples of the northern Cape (Morris, 1984), the Iron Age archaeological populations of K2/Mapungubwe (Steyn, 1994) and Toutswe (Mosothwane, 2004), the archaeological Stone Age hunter-gatherers from Oakhurst (Patrick, 1989), as well as modern populations (late 19th and 20th century) that included a 20th century post-antibiotic Venda community (L'Abbé, 2005), a 19th century mining community from Kimberley (Van der Merwe, 2006), Koffiefontein (L'Abbé et al., 2003) and Maroelabult (Steyn et al., 2002b). Of these populations, Riet River and Kakamas are probably the most relevant groups for comparison, as they are Khoesan individuals of protohistoric origin.

Lastly, skeletal growth was assessed including only individuals for which a reliable dental age could be estimated. Maximum diaphyseal lengths (excluding epiphyses) were measured for 
all upper and lower limb long bones present, and data for both sexes were pooled. The averages for all long bones per age group were calculated and compared with data from Mapungubwe/K2 (Steyn, 1994), Toutswe (Mosothwane, 2004), Arikara (Merchant \& Ubelaker, 1977) and Lovejoy \& colleagues (1990).

\section{Results}

The sample comprised 53 men, 71 women and 31 individuals of unknown sex (mostly juveniles) (Table 1). Middle-aged adults form the largest age group $(n=44,28.4 \%)$, followed by younger adults ( $n=40,25.8 \%)$. A large number of deaths were also seen in individuals younger than 20 years $(n=53,34.2 \%)$ (Table 2$)$.

Table 1. Sex distribution

Sex

$\begin{array}{cc}N & \% \\ 53 & 34.2 \\ 71 & 45.8 \\ 31 & 20.0 \\ 155 & 100\end{array}$

Male

34.2

Female

45.8

Unknown

100

Total

$N$, number of individuals.

\section{Table 2. Age distribution}

Age range in years

0-2 (infants)

N $\quad \%$

$15 \quad 9.7$

3-10 (juveniles)

$16 \quad 10.3$

11-19 (adolescents)

$22 \quad 14.2$

20-39 (young adults)

$40 \quad 25.8$

40-59 (middle adults)

$44 \quad 28.4$

$59+$ (older adults)

$8 \quad 5.2$

$>20$

$6 \quad 3.9$

$>40$

21.3

Unknown

Total 155

$N$, number of individuals.

Of the 155 individuals, 83 were affected by one or more pathological conditions. Specific skeletal pathology encountered in this study is summarised in Table 3. 
Table 3. Specific skeletal pathology

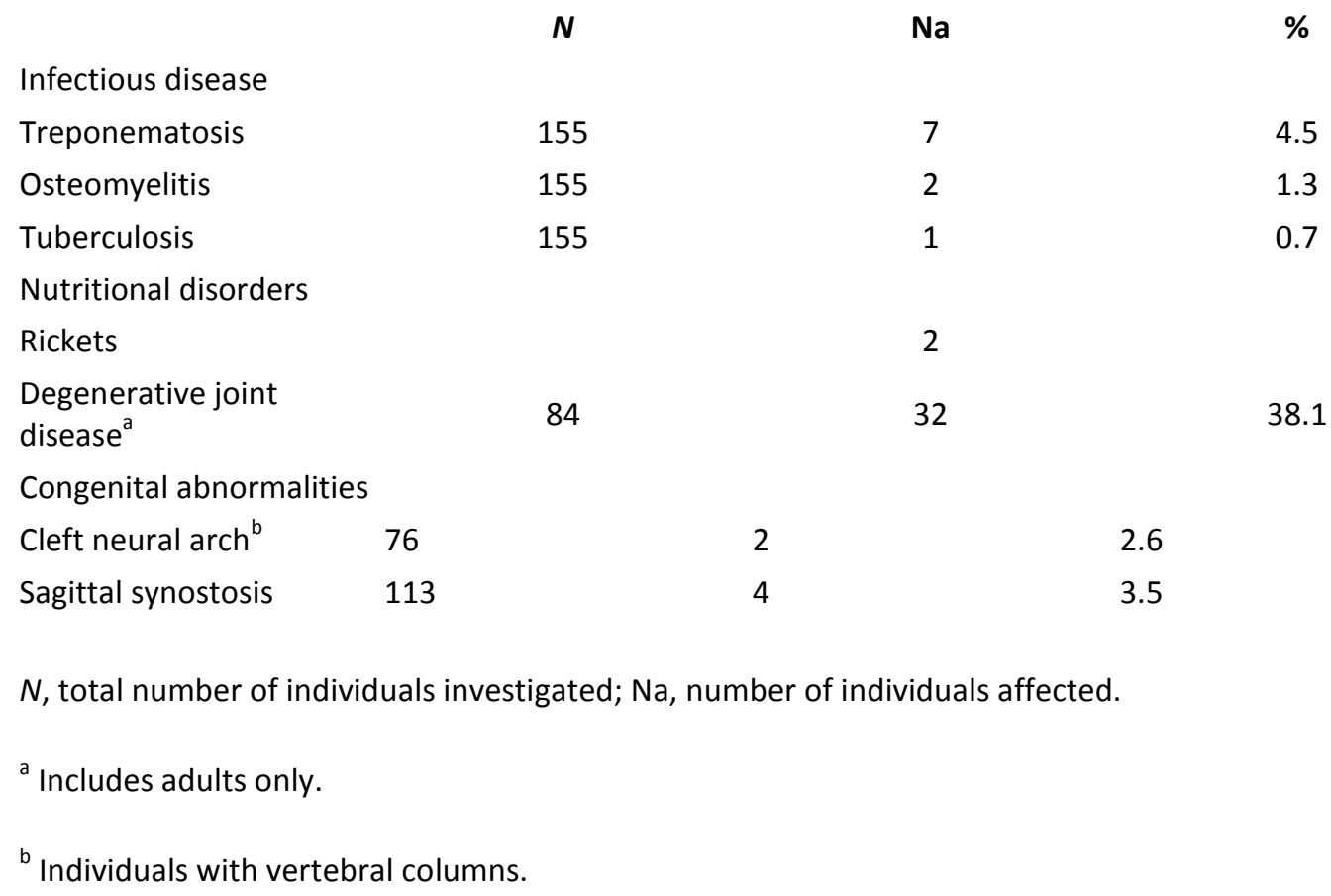

Seven individuals (4.5\%) showed signs of possible treponematosis, including five adults (four men and one woman), one adolescent and one juvenile. In order to determine which form of treponematosis is present in a skeletal sample, one needs to take into consideration geographical location as well as skeletal location. Venereal treponematosis is found worldwide, while yaws and bejel occur in the tropical areas. Also, venereal treponematosis is the only form of the disease with a congenital variant (Roberts \& Manchester, 1995; Waldron, 2009). Treponemal disease encountered in this study is thus most likely the venereal form of infection because of it occurring in the southern, more arid parts of Africa and because of the presence of a possible case of congenital treponematosis.

The juvenile, aged 7 to 9 years (S64), presented with possible congenital treponemal disease. Thickening of the diaphyses, anterior bowing of the lower limb and periostitis of the long bones are features that have generally been associated with congenital venereal disease (Toohey, 1985; Rasool \& Govender, 1989; Aufderheide \& Rodríguez-Martín, 1998). The right tibia and femur showed signs of advanced periostitis and thickening of the diaphyses. The left femur had periostitis, as well as osteomyelitic changes and cloaca formation (most likely indicative of haematogenous pyogenic osteomyelitis). Unfortunately, the left tibia was lost postmortem. However, no lesions were present on the skull, and the teeth appeared normal. It is possible that the skeletal features in this case are indicative of both congenital venereal disease and pyogenic osteomyelitis, as this form of osteomyelitis is not a typical feature of congenital treponematosis (Hackett, 1975; Rasool \& Govender, 1989).

The most common skeletal features indicative of venereal treponemal disease is gummatous lesions on the cranium and sabre-shin tibiae (Hackett, 1976; Powell, 1988; Ortner, 2003; Waldron, 2009), which were the most frequently encountered lesions in individuals with possible treponemal disease in the current study. Four of the five adults and the adolescent individual had gummatous lesions on the cranium. Two adults (S7 and S42) presented with sabre-shin, as well as destruction of the nasal conchae and septum (Figure 1). 


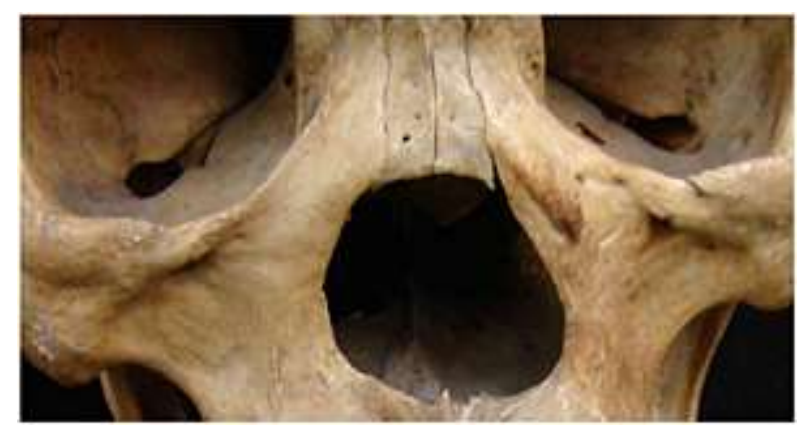

Figure 1. Destruction of the interior nasal structures in a woman (S7) aged 20 to 30 years.

Individual S42 (a man aged 40-59 years) also had periosteal reactions on all upper and lower long bones, although no gummatous lesions were found on the skull. The degree of bone involvement in this case would indicate that the disease was in an advanced state (Ortner, 2003). Although the pattern of long bone involvement is similar to diagnostic criteria for venereal disease described by Hackett $(1975,1976)$ and Waldron $(2009)$, the absence of cranial involvement may establish a diagnosis of treponemal disease with reduced confidence. Hackett (1975) stated that only when cranial lesions (caries sicca) in combination with periostitis of the long bones are present can a diagnosis of venereal disease be made with accuracy and confidence. However, the presence of bilateral long bone involvement in subperiosteal deposition of new bone and thickening of the diaphysis and metaphyses, as well as the pathological changes being most advanced in the lower legs, suggest that this may indeed be venereal treponematosis (Rothschild \& Rothschild, 1996; Mays et al., 2003).

One case of non-specific osteomyelitis was also encountered. A male individual (S123) aged 20-39 years had severe osteomyelitic changes with cloaca formation on the left radius (Figure 2). The hand bones and humerus appeared normal (no ulna present). There was no evidence of trauma or specific infectious disease, which suggests that the mode of infection may be haematogenous.

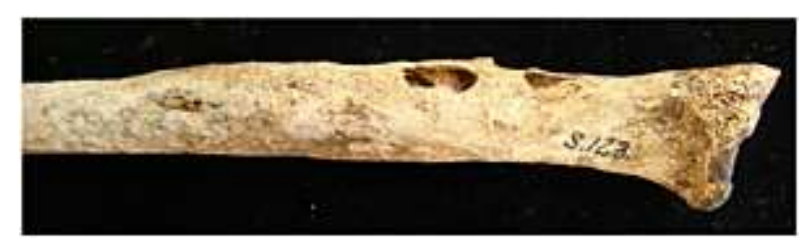

Figure 2. Non-specific osteomyelitis with cloaca formation of the left radius in an adult male individual (S123).

A man aged 40-59 years (S6) was the only individual suspected of having possible tuberculosis. The post-cranial bones were generally osteoporotic. A healed infectious lesion was present on the cranium in the area of the lambda. The visceral side of the second and third ribs, pleural side of the scapulae, os coxae and tibiae had a woven bone appearance. New bone formation was visible on the ribs (visceral side) and on the scapulae (pleural side). Although bone lesions caused by tuberculosis are essentially osteomyelitic (Roberts \& Manchester, 1995; Roberts \& Buikstra, 2003), extensive reactive bone formation throughout the skeleton has been identified as being characteristic of the disease (Ortner, 2003, 2008; Murphy et al., 2009). Despite difficulties in the diagnosis of tuberculosis, periosteal lesions 
on the ribs and scapulae have been postulated as being indicative of a pulmonary infection such as tuberculosis (Roberts et al., 1994; Santos \& Roberts, 2001; Ortner, 2003)

One should note that the lesions observed in this case may also be indicative of hypertrophic osteoarthropathy, which is recognised by widespread periostitis often affecting the scapulae, os coxae, calcaneus and long bones (Mays, 2002). Periosteal changes in the ilia and ribs, however, are less typical of hypertrophic osteoarthropathy but may appear in advanced state of disease (Ali et al., 1980; Mays, 2002). The absence of periostitis on the long bones (except for the tibiae), with the scapulae, os coxae and ribs clearly displaying bone lesions may in this case support a diagnosis of tuberculosis rather than hypertrophic osteoarthopathy.

Venereal disease and tuberculosis have been reported to be common amongst Khoesan people working and living on farms (Silberbauer, 1965; Truswell \& Hansen, 1976). Huntergatherer groups were also affected by these diseases, but infections seemed to crop up periodically rather than manifest on a long-term basis (Silberbauer, 1965).

The prevalence of infectious disease was found to be similar to that of various other South African skeletal populations, including Gladstone (Van der Merwe, 2006), Venda (L'Abbé, 2005), Mapungubwe/K2 (Steyn, 1994) and Maroelabult (Steyn et al., 2002b). No statistically significant difference was observed in terms of the prevalence of infectious disease between the current study group and these comparative populations. However, it should be taken into account that these comparative groups also represent populations under stressGladstone represents late 19th century individuals from a mining context in Kimberley, whereas Maroelabult dates back to the Second Anglo-Boer War, a time period of specific hardship in the interior of the country.

Sagittal synostosis was observed in four individuals (three adults and one adolescent). None of the crania appeared to be malformed, indicating that closure occurred when cranial growth was nearly or fully complete.

Osteoarthritis was present in 32 (38.1\%) of 84 individuals investigated for signs of degenerative joint disease. The mean age range of the 84 adult individuals in this group was 40 to 59 years. Women were significantly more affected than men $\left(\chi^{2}=6.02 ; p=0.0141\right)$. Vertebral osteophytes (19 individuals; $19.8 \%$ ) were the most common degenerative change observed, followed by osteoarthritis of the elbow joint (11 individuals; $11.5 \%$ ). A statistically significant difference was seen between the current sample and the Gladstone population $\left(\chi^{2}=4.46 ; p=0.0347\right)$, Toutswe $\left(\chi^{2}=13.78 ; p=0.0002\right)$ and Venda $\left(\chi^{2}=28.63 ; p<0.0001\right)$. The current sample was affected to a greater extent than the comparative populations, suggesting that the Khoesan's lifestyle involved considerable amounts of strenuous activity.

Two cases of rickets, both in infants (S15 and C36), were observed. Rickets occur mainly in children between 6 months and 2 years (Passmore \& Eastwood, 1986) but is not commonly encountered in southern Africa. One infant (12-18 months) had a bowed appearance of the femora, tibiae and fibulae, while another (18 \pm 3 months) had bowed femora and tibiae, but the fibulae were normal. Thickening of the bones was apparent in both cases. It may be suggested that both infants were chronically ill. CO was observed in both infants, supporting the notion of poor health in these children. 
Table 4. Non-specific skeletal pathology

$\begin{array}{lccc} & \text { N } & \text { Na } & \text { \% } \\ \text { Cribra orbitalia } & 120 & 23 & 19.2 \\ \text { Porotic hyperostosis } & 121 & 7 & 5.8 \\ \text { Periostitis } & 117 & 9 & 7.7 \\ \text { Enamel hypoplasia } & 55 & 17 & 30.9 \\ \text { Persistently open anterior } & 113 & 3 & 2.7 \\ \text { fontanelle } & & & \end{array}$

$N$, total number of individuals investigated; $\mathrm{Na}$, number of affected individuals

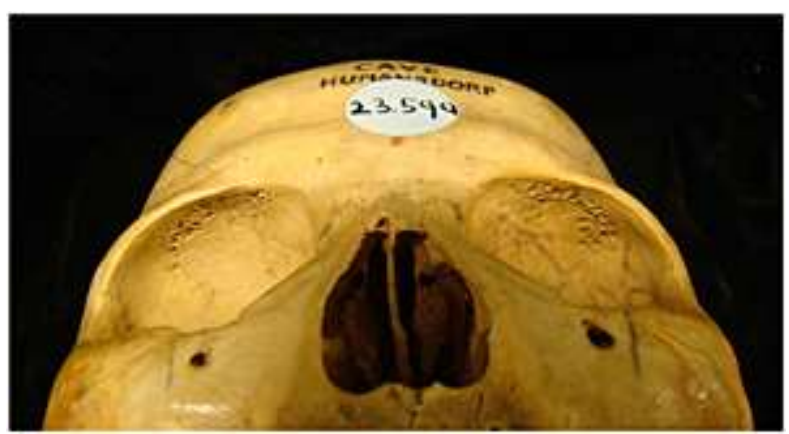

Figure 3. Cribra orbitalia in an adolescent female individual (\#23590).

Several non-specific, general disease indicators were present (Table 4). CO was observed in 23 individuals ( 14 adults, 7 juveniles and 2 infants-19.2\%) (Figure 3). The two infants and four juveniles had active lesions. Three juveniles and all of the adults had remodelled lesions. This is a higher prevalence of $\mathrm{CO}$ than what was seen in the Riet River, Kakamas and Gladstone populations which also come from the same general region. However, Oakhurst and K2/Mapungubwe displayed the highest frequency of the condition (Table 5).

Table 5. Comparison of non-specific conditions between this study and other southern African populations

\section{Sample}

Current study

Riet River

Kakamasa

Oakhursta

K2/Mapungubwea

Toutswe

Gladstone

Current study

K2/Mapungubwe

Maroelabult

Koffiefontein

\section{n}

120

74

53

18

37

35

82

117

106

47

36
$\mathrm{Na}$

$\%$

Cribra orbitalia

20

7

2

11

14

6

9

11.0

7.7

5.7

17.0

11.1

4

9.5

3.8

61.1

37.8

17.1

\section{Periostitis}

9

8

$$
\chi^{2}
$$ \\ $p$-value}

Reference

This study

0.0697 Morris (1984)

$0.0079 \quad$ Morris (1984)

$0.0001 \quad$ Patrick (1989)

$0.0192 \quad$ Steyn (1994)

0.7870 Mosothwane

(2004)

Van der Merwe (2006)

This study Steyn (1994) Steyn et al. (2002b)

L'Abbé et al. (2003) 


\begin{tabular}{|c|c|c|c|c|c|c|}
\hline Sample & $n$ & $\mathrm{Na}$ & $\%$ & $x^{2}$ & $p$-value & Reference \\
\hline Venda & 113 & 7 & 6.2 & 0.20 & 0.6547 & L'Abbé (2005) \\
\hline Gladstonea & 107 & 20 & 18.7 & 5.98 & 0.0145 & $\begin{array}{c}\text { Van der } \\
\text { Merwe (2006) }\end{array}$ \\
\hline \multicolumn{7}{|c|}{ Linear enamel hypoplasia } \\
\hline Current study & 55 & 17 & 36.9 & & & This study \\
\hline Oakhurst & 22 & 11 & 50.0 & 1.11 & 0.2930 & Patrick (1989) \\
\hline K2/Mapungubwea & 60 & 38 & 63.3 & 7.79 & 0.0053 & Steyn (1994) \\
\hline Maroelabult & 16 & 3 & 18.8 & 1.70 & 0.1919 & $\begin{array}{c}\text { Steyn et al. } \\
\text { (2002b) }\end{array}$ \\
\hline Koffiefonteina & 37 & 22 & 61.1 & 4.48 & 0.0344 & $\begin{array}{l}\text { L'Abbé et al. } \\
\qquad(2003)\end{array}$ \\
\hline Vendaa & 90 & 12 & 13.3 & 9.49 & 0.0021 & L'Abbé (2005) \\
\hline Gladstonea & 90 & 14 & 15.6 & 7.48 & 0.0062 & $\begin{array}{c}\text { Van der } \\
\text { Merwe (2006) }\end{array}$ \\
\hline
\end{tabular}

$n$, total number of individuals investigated; $\mathrm{Na}$, number of individuals affected.

${ }^{\text {a }}$ Statistically significant difference observed.

$\mathrm{PH}$ was seen in seven individuals (5.8\%), including four infants, one juvenile, one adolescent and one adult. The infants and juvenile had active lesions. Mosothwane (2004) reported that 14.3\% of individuals from Toutswe tradition sites in Botswana portrayed $\mathrm{PH}$, with the majority also being younger than the age of 20 years. Although the prevalence of $\mathrm{CO}$ in the present study is similar to that of Toutswe, $\mathrm{PH}$ was seen slightly less in the Khoesan group than in the Toutswe individuals. This difference was, however, not statistically significant.

Periostitis was observed in nine individuals (7.7\%). The tibia was most frequently affected (six of the nine individuals), followed by the fibula (four individuals). The current sample portrayed similar frequencies of the condition when compared with other populations (Table 5). A statistically significant difference was only observed between the present study and Gladstone $\left(\chi^{2}=5.98 ; p=0.0145\right)$, with the current sample much less affected.

All teeth present were investigated for macroscopically visible signs (horizontal lines) of enamel hypoplasia. Linear enamel hypoplasia was seen in 17 individuals (30.9\%), which proved to be less than reported in the K2/Mapungubwe (Steyn, 1994), Koffiefontein (L'Abbé et al., 2003) and Oakhurst (Patrick, 1989) samples but more than that observed in the Venda (L'Abbé, 2005) and Gladstone (Van der Merwe, 2006) groups (Table 5). A statistically significant difference was observed between the present sample and K2/Mapungubwe $\left(\chi^{2}=7.79 ; p=0.0053\right)$, Koffiefontein $\left(\chi^{2}=4.48 ; p=0.0344\right)$, Venda $\left(\chi^{2}=9.49 ; p=0.0021\right)$ and Gladstone $\left(\chi^{2}=7.48 ; p=0.0062\right)$.

A juvenile (S32), aged 11 to 13 years, presented with malformation of the enamel in all teeth present. Six permanent teeth (three molars and three premolars) were available for analysis. Unfortunately, the other teeth were lost post mortem. Of the skeletal elements, only the cranium and ribs were present. Figure 4 represents a first molar and two second molars (top row). It was not clear if these were upper or lower molars, as the teeth were separated from the cranium and mandible. The roots were not yet fully developed, making analysis difficult. 
The bottom row represents (from left to right) a lower first premolar and two upper first premolars. The enamel showed post mortem damage on quite a few of the teeth. Several pits and grooves could be seen on the tooth crowns. The formation and deposition of enamel appeared to have been disrupted during development. A differential diagnosis was established that included congenital treponematosis, hypoplastic amelogenesis imperfecta and cuspal enamel hypoplasia.

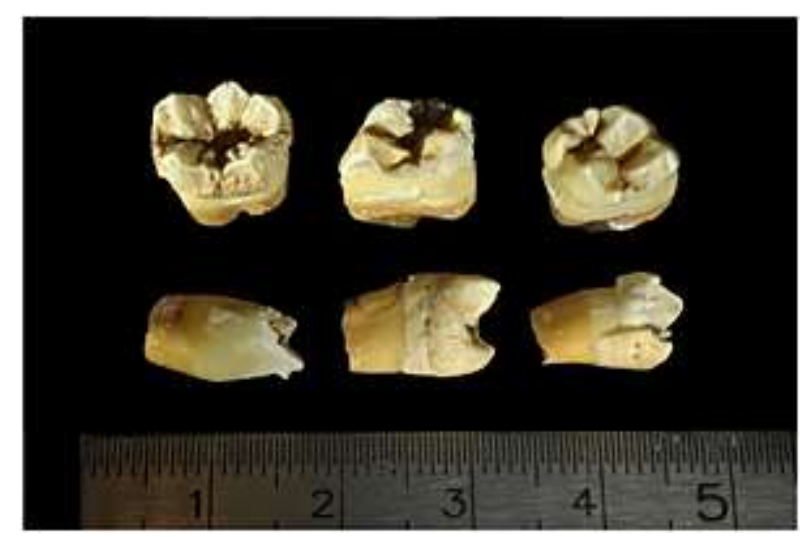

Figure 4. Severely malformed enamel crowns of permanent molars and premolars in a juvenile (S32).

Dental characteristics of the molars in congenital venereal disease include an irregular surface with a honeycomb pattern, undefined cusps and dome-shaped teeth known as Moon's molar (Cruickshank, 1939; Hillson et al., 1998). Congenital treponemal disease seems to be a likely cause of condition, because treponematosis had been encountered in adults of the study sample. Although the cusps have an irregular appearance, they lack the typical features associated with Moon's molar. Furthermore, no other skeletal lesions such as periostitis could be established because of the lack of skeletal elements. Therefore, a diagnosis of congenital treponematosis can only be made with low accuracy.

Another possible cause of the condition may be a genetic defect such as a hypoplastic form of amelogenesis imperfecta. This defect often causes the enamel crowns to have deep pits and grooves, as well as a brittle appearance (Cawson \& Odell, 2002). In some cases, the crown appears as a sharp cusp with a thin layer of hard enamel (Soames \& Southam, 1993), which is seen in this case. Although the features of the teeth investigated here are similar to that described for hypoplastic amelogenesis imperfecta, it is a difficult diagnosis to make as there are limited data published on the prevalence of this defect in southern African groups.

A severe form of enamel hypoplasia, such as cuspal enamel hypoplasia (Ogden, 2008), may also have caused the disruption in cusp pattern formation. The malformation of the enamel crowns, as well as the young age at death and the presence of $\mathrm{CO}$, suggest that this individual was in poor health. Whatever the cause of this defect, it is clear that the enamel crowns were permanently damaged and the structure of the dentine affected.

Three infants (S9, S11 and C35) presented with delayed closure of the anterior fontanelle (Figure 5), which is often associated with poor health and chronic illness, although several explanations have been posed to explain this phenomenon including genetic abnormalities, endocrine disorders and malnutrition (Behrman et al., 1992; Ortner, 2003). Furthermore, S11 and C35 presented with periostitis of the tibia and of the fibulae and radii, respectively. 
This suggests that these individuals suffered from possible chronic infection and/or malnutrition. Large anterior fontanelles have also been noted in an early 20th century rural population from the North West Province (Maroelabult), South Africa, in which four individuals presented with the phenomenon (Steyn et al., 2002a) and probably attest to the poor health and marginalisation of these groups.

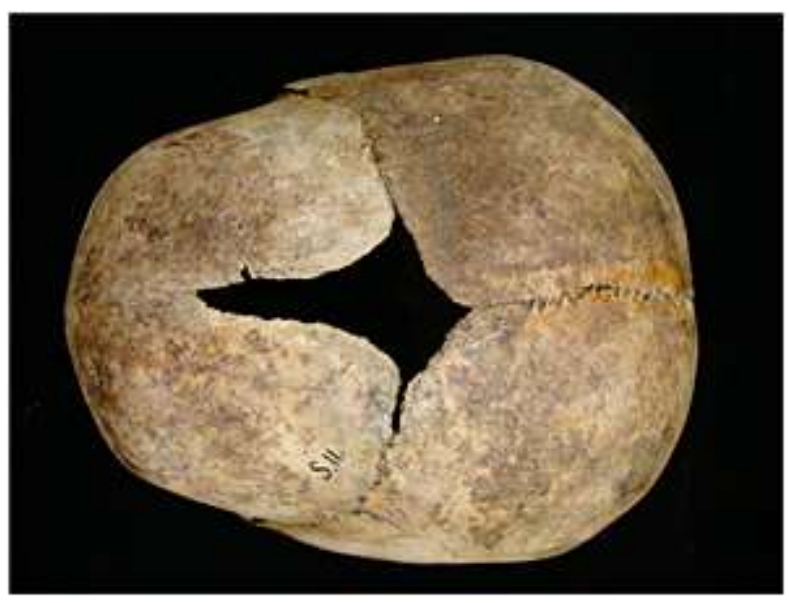

Figure 5. Open anterior fontanelle in an infant (S11) aged 15 to 18 months.

A total of 13 individuals were affected by trauma in this study (Tables 6 and 7). Three crania (two women and one man) showed signs of healed depressed fractures, of which two were found on the parietal bones and one on the occipital bone.

Table 6. Trauma-summary of cranial and post-cranial lesions

$\begin{array}{ccc}n & \text { Na } & \% \\ 113 & 3 & 2.7 \\ 122 & 6 & \\ 122 & 2 & 4.9 \\ 122 & 1 & 1.6 \\ 122 & 1 & 0.8 \\ 122 & 1 & 0.8 \\ & 1 & 0.8\end{array}$

Cranial lesions (healed) $\%$

Post-cranial lesions

Antemortem fractures

Perimortem fractures

0.8

$n$, total number of individuals investigated; $\mathrm{Na}$, number of individuals affected.

\section{Table 7. Details of trauma cases}

\begin{tabular}{|c|c|c|c|}
\hline Individual & Age & Sex & Trauma description \\
\hline S4 & $\begin{array}{l}20- \\
39\end{array}$ & $\mathrm{~F}$ & Well-healed fracture of the $L$ proximal humerus \\
\hline S8 & $\begin{array}{l}20- \\
39\end{array}$ & $\mathrm{~F}$ & Bilateral spondylolysis of the fourth lumbar vertebra \\
\hline S10 & $\begin{array}{l}20- \\
39\end{array}$ & M & Hangman's fracture (perimortem fracture of axis) \\
\hline S24 & $\begin{array}{l}40- \\
59\end{array}$ & M & $\begin{array}{l}\text { Healed fracture of the } L / R \text { ulna, partially healed fracture of the } L \text { femoral head, second } \\
\text { unhealed fracture in subtrochanteric area of } L \text { femur }\end{array}$ \\
\hline S47a & $\begin{array}{l}20- \\
39\end{array}$ & $\mathrm{~F}$ & Well-healed cranial lesion on the R parietal bone \\
\hline S53 & $20-$ & M & Fused pubic symphyses, possibly due to trauma in the area of the pubic bones \\
\hline
\end{tabular}


39

S61 20-

$39 M$ Pseudoarthrosis of the L clavicle

S67 $59+M \quad$ Well-healed cranial lesion on the $\mathrm{R}$ parietal bone

S75/S58 $\begin{aligned} & 20- \\ & 39\end{aligned}$

S95 $\quad \begin{aligned} & 20- \\ & 39\end{aligned} \quad M \quad$ Well-healed fracture of the $L$ femoral shaft

S107 $\quad \begin{aligned} & 40- \\ & 59\end{aligned}$

S108 $\quad \begin{aligned} & 40- \\ & 59\end{aligned}$

S112 $\quad \begin{aligned} & 40- \\ & 59\end{aligned} \quad$ Healed parry fracture of the L/R ulna

$L$, left; R, right.

Eight individuals (four men and four women, 6.6\%) had post-cranial trauma. Single fractures were seen in all four women and three men. Only one man (S24) presented with multiple fractures.

Antemortem trauma was observed in six individuals. Two women (S107 and S112) presented with possible parry fractures of the ulna. These fractures were well healed and remodelled. Well-healed fractures were also seen in the left femoral shaft (Figure 6) of a male individual (S95) and left proximal humerus (Figure 7) of a female individual (S4). Secondary osteoarthritis of the os coxa (male individual) was evident as a result of the injury sustained. The femoral fracture is also malunited, suggesting that it could not be immobilised properly before healing took place. As a result of the humeral fracture sustained in the female individual, complete ankylosis of the shoulder joint occurred. This would have resulted in immobility of the upper left limb. Pseudoarthrosis of the left clavicle (Figure 8) was seen in a man (S61). Healing of the fracture was not successful, although signs of bone remodelling were present. This most likely resulted because of constant movement, preventing the fracture from healing.

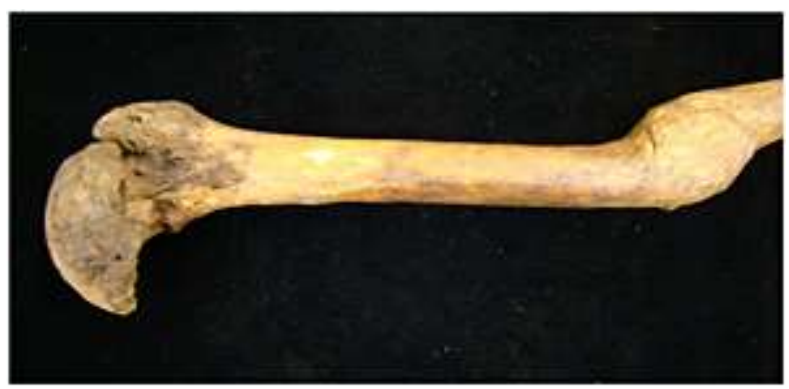

Figure 6. Healed fracture of the femur in an adult male individual (S95). 


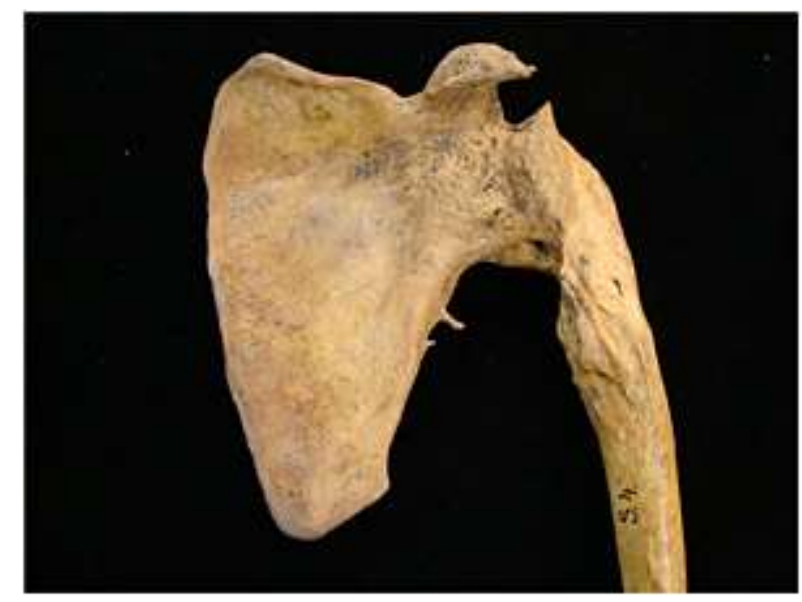

Figure 7. Healed fracture of the humerus in an adult female individual (S4).

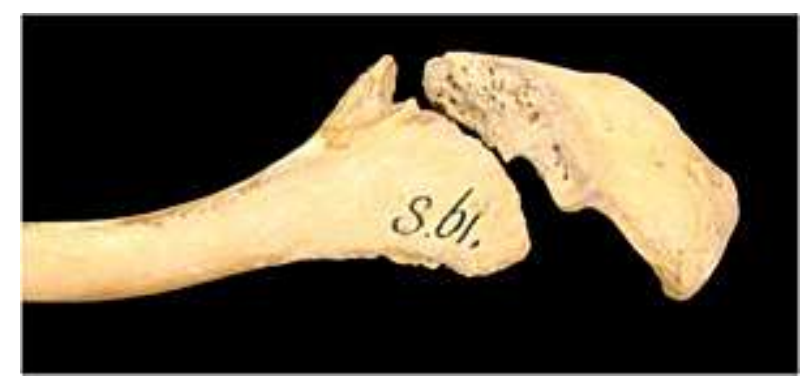

Figure 8. Pseudoarthrosis of the left clavicle in an adult man (S61).

Individual S24 (a man aged 40 to 55 years) sustained multiple fractures, which included a well-healed fracture of the left ulna (a possible parry fracture), a fracture of the left femoral head that had healed only partially and a fracture in the subtrochanteric area of the left femur which may have occurred shortly before death as almost no healing was observed. The complete left leg appeared largely porotic in comparison with the rest of the skeleton, which may have resulted from the leg not being used because of discomfort caused by the fracture of the femoral head. The osteoporotic state of the femur may have been the cause of the fracture that occurred in the subtrochanteric area. It is possible that the fractures to the ulna and femoral head were caused by the same traumatic event, with the third fracture (subtrochanteric fracture of the femur) occurring as a complication of the initial injuries.

Antemortem trauma encountered in the sample illustrates that these individuals had poor or no access to health care, as healed fractures showed no signs of medical intervention (i.e. surgical repair or proper fracture alignment) in order to assist in the healing process.

Perimortem trauma was seen in two individuals. A man, S10, presented with a hangman's fracture (Figure 9). Both pedicles and articular facets of the axis were fractured which ended in the vertebral body. Hanging causes forcible hyperextension of the head, giving rise to this type of fracture (Segen, 2005). Records stated that this individual was put to justice by means of hanging in Botswana during 1910 (Pacher, 1961). The crime punishable by death is, however, unknown in this case. A woman, S108, presented with rib fractures of the fourth, fifth and sixth ribs that showed no signs of healing. The injury probably occurred around the time of death. 


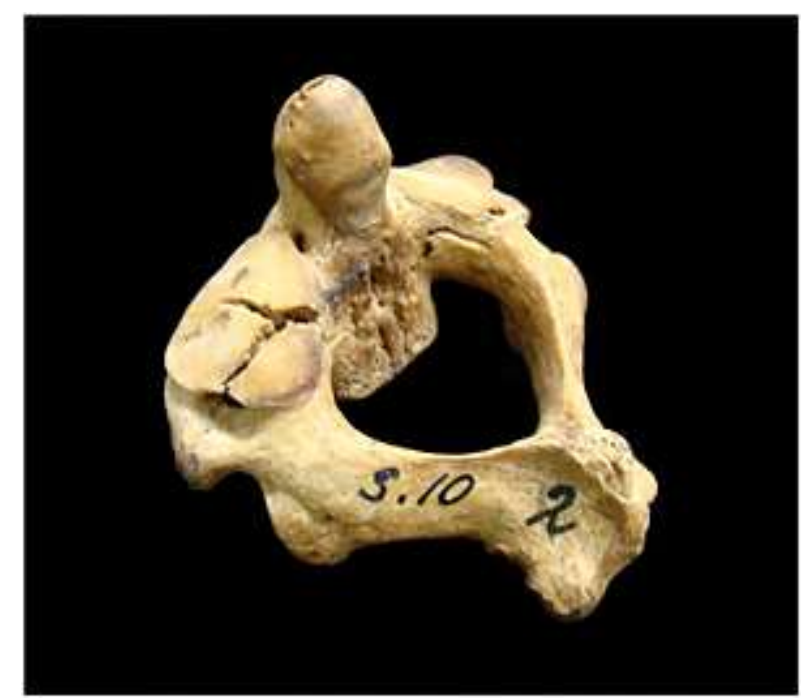

Figure 9. Hangman's fracture in an adult male individual (S10).

The incidence of fractures in this study was found to be similar to that of the Venda population ( $n=8 ; 7.1 \%)$. However, a highly significant difference was seen between the current sample and the Gladstone population $\left(\chi^{2}=26.566 ; p<0.0001\right)$, with the Khoesan group much less affected. These results suggest that the current study group did not sustain as many work-related injuries as seen in the mineworkers from Gladstone but rather suffered occasional injuries brought about by isolated accidents or events.

Spondylolysis was evident in only one woman (S8), where bilateral separation of the neural arch of $L 4$ occurred. Spondylolysis appears to be common in populations that practise extreme physical labour causing excessive strain on the lower back, such as mining. This group appeared to not have taken much part in activities that exerted excessive strain on the lower back, although vertebral osteophytes were common.

Skeletal growth assessment revealed shorter lengths of all the bones from ages 4.5-5.5 to $5.5-6.5$, but this is likely an artefact of the small sample size $(n=19)$. No individuals were present in the 7.5-8.5 and 9.5-10.5 age groups. Figures 10 and 11 show growth rates for the humerus and femur, respectively.

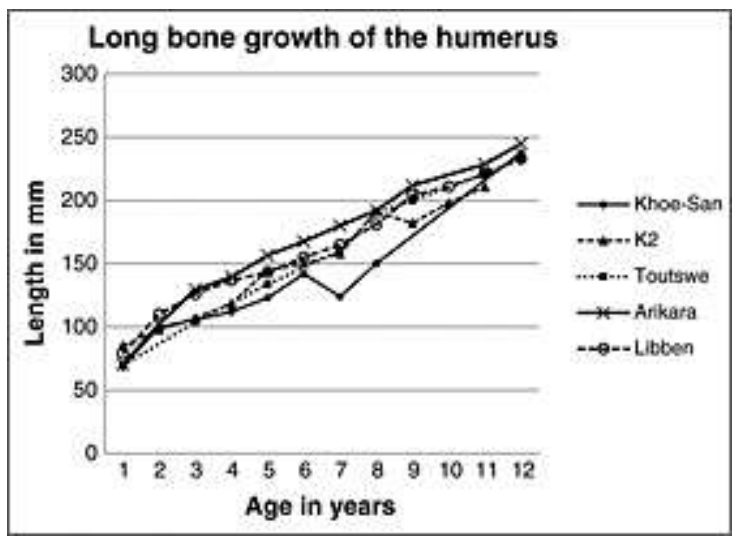

Figure 10. Growth rate of the humerus. 


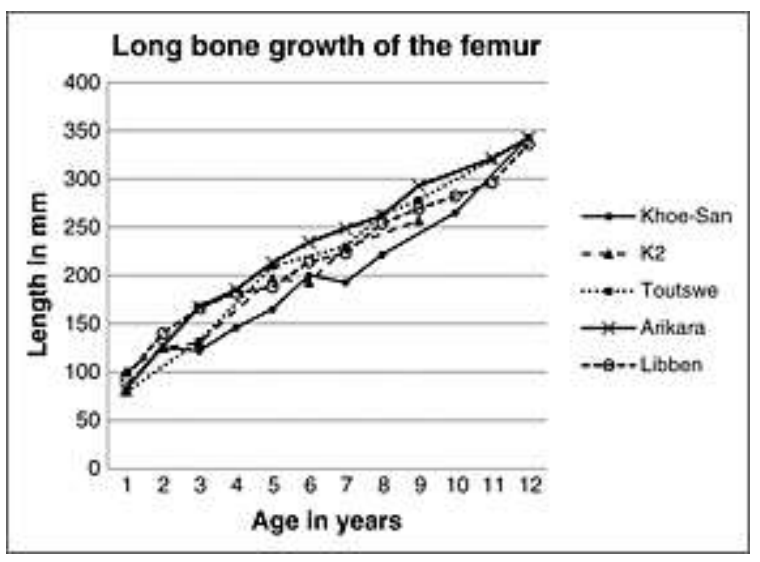

Figure 11. Growth rate of the femur.

The lengths of all long bones were, in general, shorter than that of comparative populations. During the early years of life (newborn to about 2 years), the growth rate of the Khoesan children appeared to be similar to that of the other groups. However, after that the growth rate decreased and from about 3 years onwards the long bone lengths of the Khoesan juveniles remained below the average lengths of the comparative groups. However, the general trend of the growth chart for all the long bones in this study appeared to follow a normal growth pattern with no definite or severe stunting observed at any stage.

\section{Discussion}

This study sample is heterogeneous, as the skeletons were collected from various places in southern Africa and represents individuals of San and Khoe origin. The sample also, most likely, contains San or Khoe individuals with possible white or black admixture. The group is thus representative of the larger Khoesan population as they were found during the late 19th and early 20th centuries throughout southern Africa.

The broad demographic profile of the Khoesan group reveals characteristics similar to other populations from the same time period, for example the Venda (L'Abbé, 2005), although one should take into account that these individuals may not be entirely representative of the once-living population. However, it was decided that statistical comparisons could be performed between this and other southern African groups as the sample reflects a normal age distribution. The number of men and women in the sample are about equal, but collection practices may have favoured equality in numbers between men and women instead of revealing the actual man-woman ratio of the Khoesan population at the time.

There may be several problems deducing an accurate health status from the sample at hand as far as the actual Khoesan group is concerned. As Wood \& colleagues (1992) explained, the skeletal remains constituting the sample are not an accurate representation of the onceliving population. One should thus be mindful of the fact that assumptions regarding demographic profile and prevalence of disease are merely reconstructions of past realities and may not accurately reflect estimates of the group in past times.

The marginalisation and transition from a hunter-gatherer subsistence or pastoralism to colonial farms/urban environments brought about a drastic change in the lifestyle of the 
Khoesan, which most probably caused a decline in their health status. The new living conditions were most likely sedentary, which promoted poor sanitation and hygiene and a decline in variety of foods consumed. The manifestation and spread of infectious diseases was most likely a direct result of this change - from vast, open, dry spaces to crowded living conditions. Khoesan individuals were employed on farms as cattle herders, unskilled workers and domestic servants together with individuals from other black African groups, where they received low wages and rations of corn meal, tea, sugar and tobacco. Living in close proximity to their fellow employees most likely increased the Khoesan's exposure to infections such as treponemal disease and tuberculosis. Their health was most likely compromised by the absence of a balanced diet, poverty, increased contact to pathogenic micro-organisms due to poor living conditions and hard physical labour on farms for long periods of time (Guenther, 1976; Smith et al., 2000; Mountain, 2003).

The presence of multiple non-specific indicators suggests that this group experienced considerable physiological hardships. All lesions indicative of $\mathrm{CO}$ and $\mathrm{PH}$ were found to have developed during childhood, as the adults displayed remodelled lesions. $\mathrm{CO}$ and $\mathrm{PH}$ normally develop during childhood, as children tend to be more sensitive to environmental stressors (Ortner, 2003).

The development of rickets was most likely secondary rather than primary, as this condition is rare amongst African groups. Causes that may possibly lead to secondary development of rickets include malnutrition and infectious disease (Ortner, 2003). Truswell \& Hansen (1976) reported that only mild malnutrition was encountered in the traditional Khoesan because of seasonal availability of a variety of foods but that no severe nutritional disorders were seen. Various plant species gathered in the veldt provided excellent nutrition to traditional Khoesan groups, although the quantity of such sources were often unreliable in the dry season (Tanaka, 1976). It is thus unlikely that individuals that formed part of a huntergatherer subsistence economy would have developed a vitamin $D$ deficiency because of their diet being insufficient. This group most likely contained few individuals who lived by hunting and gathering alone, although the presence of such individuals cannot be ruled out.

Malnutrition due to poverty and hunger experienced by farm Bushmen should also be considered in this group. Rations received by labourers typically consisted of maize and tobacco and on the odd occasion meat (Silberbauer, 1965; Schoeman, 2009). This suggests that their diet was deprived of several essential nutrients to sustain a healthy lifestyle. Excessive tobacco usage was also common amongst the Khoesan, which would have aided in decreased absorption of nutrients and increased pulmonary disease (Silberbauer, 1965; Navarra, 2004).

Infants affected by infection and other disease may have been kept indoors for longer periods of time than healthy infants. Both infants with possible rickets in this study also had $\mathrm{CO}$ and periostitis, which may suggest the presence of other conditions or ill health. Malaria was common amongst hunter-gatherer groups during the wet season (Truswell \& Hansen, 1976), which would have aided in the pathogen load and biological stress experienced by both adults and children. Whether the two infants in the present study developed rickets by being kept indoors because of acute infection, cultural habit or both is not clear, but they 
were in poor health at the time and possibly died because of a combination of infection and malnutrition.

Several causes of periostitis have been proposed, but the most frequently implicated is trauma or infection (Aufderheide \& Rodríguez-Martín, 1998; Roberts \& Manchester, 1995). It is possible that many Khoesan individuals suffered from chronic infection and/or traumatic events as they came in contact with complex social and economic structures. An increase in population density and crowding of living spaces often enhances the spread of infection, leading to more individuals developing periostitis if long-term infection persists (Larsen, 1997).

There are several infections, metabolic conditions and endocrine disorders that may affect the formation of dental enamel. Enamel hypoplasia serves as an indication that the presence of acute episodes of disease or malnutrition compromised the health of the individual, subsequently causing a disturbance in the process of enamel formation during childhood (Goodman \& Rose, 1991; Hillson, 2000). Specific diseases such as treponematosis may affect the normal development of teeth, leading to a disruption in enamel formation (Hillson et al., 1998). It has also been suggested that vitamin $D$ deficiency may cause poor mineralisation of enamel. Calcium is essential for enamel formation, and calcium absorption is reduced when vitamin $D$ levels are lowered. With reduced calcium levels, the process of enamel formation (amelogenesis) is disrupted. Also, the presence of enamel hypoplasia may manifest before classic skeletal signs of rickets develop (Kunzel, 2003).

When comparing the presence of enamel hypoplasia in the present sample with those of other South African studies, the K2/Mapungubwe (Steyn, 1994) and Koffiefontein (L'Abbé, 2003) samples presented with a significantly higher frequency of enamel hypoplasia than encountered in the current study. The Gladstone (Van der Merwe, 2006) and Venda (L'Abbé, 2005) samples, however, had significantly lower incidences of enamel hypoplasia. The miners from Gladstone were mostly young adult migrant labourers who were probably in good health, but experienced considerable hardship once they started employment on the mines. This is reflected in their low incidences of hypoplasia but higher occurrence of other conditions. Children in the current group thus frequently suffered from acute episodes of ill health, and it is clear that the hardships encountered affected both adults and children.

Of the major joints, the elbow $(n=11)$, followed by the shoulder $(n=7)$ and knee $(n=7)$, was mostly affected by osteoarthritis. These results are consistent with a study performed by Bridges (1991), which stated that these three joints were most commonly affected in both hunter-gatherers and agriculturalists. The patterning of arthritis, however, may not be related to subsistence economy, and it is possible that groups whose lifestyle involves a high degree of physical activity, regardless of differences in their lifestyle, may portray the same pattern of osteoarthritis when looking at the major joints. It is unclear when looking at the pattern of osteoarthritis whether the individuals in this study were exclusively huntergatherers or farm workers.

Women were more frequently affected by degenerative disease than men were, especially in the vertebrae and elbows. Sexual dimorphism related to osteoarthritis varies considerably between skeletal samples (Bridges, 1991). Some studies report that for pre-agricultural groups, women tend to show lower frequencies of osteoarthritis in the shoulder (Larsen, 
1982). However, this is not the case with the current group. High frequencies of osteoarthritis in the shoulder and elbow of women suggest that they performed physical duties mainly using the upper limbs, for example washing clothes and grinding maize.

Several traumatic lesions were encountered in this study. The presence of three healed cranial lesions (depressed fractures) to the posterior part of the cranium as well as two parry fractures suggests some degree of interpersonal violence or violence between the Khoesan and other groups or law enforcement officials. Interpersonal violence may increase within a group when they are subjected to environmental stress and deterioration, because of an increase in competition for resources (Torres-Rouff \& Costa Junqueira, 2006). Traditional Khoesan groups have been reported to show little to no violence against one another and are believed to be peaceful in nature (Bannister, 1991; Smith et al., 2000). However, it has also been reported that the Khoesan individuals living in the Cape Colony were easily tempted and often indulged in liquor. Strong drink was often given to farm workers as gifts or rewards, instead of increasing wages. It soon became clear to the European settlers that the Khoesan enjoyed alcohol. Their addiction to strong drink made them vulnerable to exploitation by the farm owners in terms of wage agreements and trading (Theal, 1905; Schoeman, 2009). It is thus possible that alcohol abuse within Khoesan groups contributed towards interpersonal violence. Both cases of parry fractures and two of the three cranial lesions were seen in female individuals, which suggests that the women may have been subjected to male violence.

It is likely that there was competition between the Khoesan and other African groups for employment on farms by the European settlers. Individuals of black African groups were taller and stronger and thus more popular as farm labourers (Guenther, 1976), placing the Khoesan at a disadvantage in terms of finding work, which may have contributed to violence occurring between Khoesan and other black African groups. Also, with the merging of Khoekhoe and San groups with other African groups on farms and in urban areas in the Cape Colony, cultural differences may have ignited aggressive behaviour amongst individuals where living spaces were shared.

The relationship between farmers and Khoesan labourers were mostly one of interdependence without excessive violence (Guenther, 1976), as farmers exchanged blankets and tobacco for marama beans, a staple food collected by the Khoesan in the veldt (Tanaka, 1976), during seasons of drought. However, ill feelings between the Dutch farmers and the Khoesan developed, as many cases of livestock theft and slaughtering of farm animals involving Khoesan individuals were reported (Penn, 2005). Stock theft would undoubtedly have caused the involvement of law enforcement officials, which may have led to violent attacks on the Khoesan.

Individuals found guilty of offences such as murder and stealing of livestock were sentenced to death by hanging under British Colonial law, which ruled throughout southern Africa from the 17th to 19th centuries (Penn, 2005). The Hangman's fracture seen in a male individual indicated that he had died by hanging and was possibly sentenced to death for stealing and killing of livestock.

The frequency of post-cranial fractures was lower than in other groups, including the Venda and Gladstone populations. The exact aetiology of post-cranial traumatic lesions observed in 
this study could not be pinpointed but appeared to be relatively low in frequency. It is possible that many of the injuries observed in the late 19th and early 20th century Khoesan may be more violence related than seen in any of the comparative groups, as no specific lifestyle activity (such as mining) causing numerous traumatic lesions stands out in this group. Hunting, however, was still performed amongst smaller groups that remained living in the veldt (Tobias, 1959; Mountain, 2003). Six of the 11 individuals affected by trauma were female, ruling out the possibility that hunting accidents could have accounted for most of the traumatic events encountered, as it can be assumed that it was predominantly the men that hunted.

Assessment of long bone growth in juvenile individuals revealed that within the first 2 years of life growth rates appear to be similar to that of the comparative populations, but reduced growth is seen from about 3 years onwards for all the long bones (Merchant \& Ubelaker, 1977; Lovejoy et al., 1990; Steyn, 1994; Mosothwane, 2004). Khoesan children were shorter than those of all the comparative populations. Although a normal growth pattern is evident in the present sample, reduced growth rates during childhood resulted in relatively smaller adult statures. Small body size and stature has mostly been ascribed to malnutrition and chronic disease, but the slow growth rates observed in Khoesan populations most likely have a strong genetic component (Tobias, 1961, 1962; Corlett \& Woollard, 1988; Pfeiffer \& Sealy, 2006).

Late Stone Age evidence suggests that infants were of an average size comparable with other groups from southern Africa and that the growth curve of these juveniles followed a continuation of a normal curve, but at a slower rate, that resulted in small adult stature. Small adult stature is thus the result of slow growth rates and not stunting (Harrington \& Pfeiffer, 2008; Pfeiffer \& Harrington, 2010). Therefore, it seems likely that the small body size and short stature of the Khoesan is not the result of early maturation as seen in the African pygmy groups but characteristic of a group whose genetic potential and adaptation for growth and adult stature were established as early as the Holocene (Pfeiffer \& Harrington, 2011; Pfeiffer, 2012). The growth of the subadults resulting in petite adult statures observed in this study is most likely due to a combination of genes and physiological stress.

\section{Conclusion}

Colonisation of the Cape Colony by Europeans, as well as the southward movement of black African groups during the past few centuries, forced the Khoesan into a period of transformation, in which they experienced immense pressures related to survival and cultural freedom. Western culture and colonial laws forced the Khoesan from their land, while black African groups competed with them for resources and work opportunities on Dutch farms. The Khoesan's subsequent social and economic marginalisation was confirmed by pathological lesions encountered in this study. As far as their overall health and general well-being is concerned, it was evident that the study group was subjected to infectious disease, possible malnutrition, trauma and degenerative joint disease. The presence of nonspecific disease indicators also revealed that individuals suffered from possible chronic disease, as well as acute episodes of poor health. Palaeopathological results were consistent 
with that of groups of a low socio-economic status. Also, it appears as though the children may have been particularly vulnerable.

\section{Acknowledgements}

We would like to thank Professor Gerard Weber and staff (University of Vienna), as well as Professor Alain Froment and staff members (Musée de l'Homme) for welcoming us to study their collections. We also extend our gratitude to SANPAD for funding. The research of M. Steyn is funded by the National Research Foundation (NRF) of South Africa. Any opinions, findings and conclusions expressed in this paper are those of the authors, and therefore the NRF does not accept any liability in regard thereto.

\section{References}

Ali A, Tetalman MR, Fordham EW, Turner DA, Chiles JT, Patel SL, Schmidt KD. 1980. Distribution of hypertrophic pulmonary osteoarthropathy. American Journal of Roentgenology 134: 771-780.

Asala SA. 2001. Sex determination from the head of the femur of South African whites and blacks. Forensic Science International 117(1): 15-22.

Aufderheide AC, Rodríguez-Martín C. 1998. The Cambridge Encyclopedia of Human Paleopathology. Cambridge University Press: Cambridge.

Bannister A. 1991. Bushmen: A Changing Way of Life. Struik: Cape Town.

Behrman RE, Kliegman RM, Nelson WE, Vaughan VC. 1992. Nelson Textbook of Pediatrics, 14th edn. WB Saunders: Philadelphia.

Boonzaier E, Malherbe C, Smith A, Berens P. 1996. The Cape Herders: A History of the Khoikhoi of Southern Africa. David Philip: Cape Town.

Botha D, Steyn M. 2013. Khoe-San skeletal collections in Vienna and Paris: Origin, history and context. South African Archaeological Bulletin, Goodwin Series XI: 7-12.

Bridges PS. 1991. Degenerative joint disease in hunter-gatherers and agriculturalists from the southeastern United States. American Journal of Physical Anthropology 85: 379-391.

Buikstra JE, Ubelaker DH. 1994. Standards for Data Collection from Human Skeletal Remains. Arkansas Archaeological Survey: Arkansas.

Cawson RA, Odell EW. 2002. Cawson's Essentials of Oral Pathology and Oral Medicine, 7th edn. Churchill Livingstone: London.

Cohen MN. 1989. Health and the Rise of Civilization. Yale University Press: New Haven and London.

Corlett JT, Woollard E. 1988. Growth patterns of rural children in the Kgalagadi region of Botswana. Annals of Human Biology 15: 153-159.

Cruickshank LG. 1939. The dental stigmata of congenital syphilis. Proceedings of the Royal Society of Medicine: Section of Odontology 32: 343-348. 
Falys CG, Lewis ME. 2011. Proposing a way forward: A review of standardisation in the use of age categories and aging techniques in osteological analysis (2004-2009). International Journal of Osteoarchaeology 21: 704-716.

Goodman AH, Rose JC. 1991. Dental enamel hypoplasias as indicators of nutritional status. Advances in Dental Anthropology, MA Kelley, CS Larsen (eds). Wiley-Liss: New York; 279-293.

Guenther MG. 1976. From hunters to squatters: Social and cultural change among the Farm San of Ghanzi, Botswana. Kalahari Hunter-Gatherers: Studies of the !Kung San and Their Neighbors, RB Lee, I DeVore (eds). Harvard University Press: Cambridge, Massachusetts and London; 120-133.

Hackett CJ. 1975. An introduction to diagnostic criteria of syphilis, trepnarid and yaws (treponamatoses) in dry bones, and some implications. Vichows Arch. A, Pathology, Anatomy and Histology 368: 229-241.

Hackett CJ. 1976. Diagnostic Criteria of Syphilis, Yaws and Treponarid (Treponematoses) and of Some Other Diseases in Dry Bones (for Use in Osteo-archaeology). Springer: Berlin.

Harrington L, Pfeiffer S. 2008. Juvenile mortality in southern African archaeological contexts. South African Archaeological Bulletin 63: 95-101.

Hillson SW. 2000. Dental pathology. Biological Anthropology of the Human Skeleton, MA Katzenberg, SR Saunders (eds). Wiley-Liss: New York; 249-286.

Hillson SW, Grigson C, Bond S. 1998. Dental defects of congenital syphilis. American Journal of Physical Anthropology 107: 25-40.

Inskeep RR. 1978. The Bushmen in prehistory. The Bushmen, PV Tobias (ed.). Human \& Rousseau: Cape Town; 33-56.

Işcan MY, Steyn M. 2013. The Human Skeleton in Forensic Medicine, 3rd edn. Charles C Thomas: Springfield.

Kunzel W. 2003. Die hypomineralisation bei molaren und incisiven. Zahnärztl Mitt 93: 1626-1629.

L'Abbé EN. 2005. A palaeodemographic, palaeopathologic and morphologic study of the 20th century Venda. PhD Thesis, University of Pretoria.

L'Abbé EN, Henderson ZL, Loots M. 2003. Uncovering a nineteenth-century typhoid epidemic at the Koffiefontein Mine, South Africa. World Archaeology 35(2): 306-318.

Larsen CS. 1982. The anthropology of St. Catherines Island. 3. Prehistoric human biological adaptation. New York: The American Museum of Natural History. Anthropology Papers 57: 157-276.

Larsen CS. 1997. Bioarchaeology: Interpreting Behavior from the Human Skeleton. Cambridge University Press: Cambridge.

Larsen CS. 2000. Skeletons in Our Closet: Revealing Our Past through Bioarchaeology. Princeton: Princeton University Press.

Lee RB. 1979. The !Kung San: Men, Women and Work in a Foraging Society. Cambridge University Press: Cambridge. 
Legassick M, Rassool C. 2000. Skeletons in the Cupboard: South African Museums and the Trade in Human Remains, 1907-1917. McGregor Museum: Kimberley.

Lovejoy CO, Russell KF, Harrison ML. 1990. Long bone growth velocity in the Libben population. American Journal of Human Biology 2: 533-541.

Mann RW, Hunt DR. 2005. Photographic Regional Atlas of Bone Disease: A Guide to Pathological and Normal Variation in the Human Skeleton, 2nd edn. Charles C. Thomas: Springfield, Illinois.

Mays S. 2002. Osteological and biomolecular study of two possible cases of hypertrophic osteoarthropathy from Mediaeval England. Journal of Archaeological Science 29: 1267-1276.

Mays S, Crane-Kramer G, Bayliss A. 2003. Two probable cases of treponemal disease of Medieval date from England. American Journal of Physical Anthropology 120: 133-143.

Mensforth R, Lovejoy CO, Armelagos GJ. 1978. The role of constitutional factors, diet, and infectious disease in the etiology of porotic hyperostosis and periosteal reactions in prehistoric infants and children. Medical Anthropology 2: 1-59.

Merchant VL, Ubelaker DH. 1977. Skeletal growth of the protohistoric Arikara. American Journal of Physical Anthropology 46: 61-72.

Mittler DM, Van Gerven DP. 1994. Developmental, diachronic and demographic analysis of cribra orbitalia in the medieval Christian population of Kulubnarti. American Journal of Physical Anthropology 93: 287-297.

Morris AG. 1984. An osteological analysis of the proto-historic populations of the Northern Cape and western Orange Free State, South Africa. PhD Dissertation, University of the Witwatersrand.

Morris AG. 1992. The Skeletons of Contact: A Study of Protohistoric Burials from the Lower Orange River Valley, South Africa. Witwatersrand University Press: Johannesburg.

Morris AG, Scholtz Y. 2013. A historical note and preliminary assessment of the human skeletal remains from southern Africa stored in the United Kingdom. South African Archaeological Bulletin, Goodwin Series XI: 21-26.

Mosothwane MN. 2004. Skeletal characteristics and population demography as reflected by materials from Toutswe tradition sites in Eastern Botswana, west of the Shashe-Limpopo Basin. MSC Dissertation, University of Pretoria.

Mountain A. 2003. The First People of the Cape. David Philip: Claremont.

Murphy EM, Chistov YK, Hopkins R, Rutland P, Taylor GM. 2009. Tuberculosis among Iron Age individuals from Tyva, South Siberia: Palaeopathological and biomolecular findings. Journal of Archaeological Science 36: 2029-2038.

Navarra T. 2004. The Encyclopedia of Vitamins, Minerals and Supplements. 2nd ed. New York: Tova Navarra.

Ogden A. 2008. Advances in the palaeopathology of teeth and jaws. Advances in Human Palaeopathology, R Pinhasi, S Mays (eds). John Wiley \& Sons: Chichester, UK; 283-307. 
Ortner DJ. 2003. Identification of Pathological Conditions in Human Skeletal Remains, 2nd edn. Oxford: Elsevier Academic Press.

Ortner DJ. 2008. Differential diagnosis of skeletal lesions in infectious disease. Advances in Human Palaeopathology, R Pinhasi, S Mays (eds). John Wiley \& Sons: Chichester, UK; 191-214.

Pacher VH-M. 1961. Anthropologische Untersuchungen an den Skeletten der Rudolf Pöch'schen Buschmannsammlung. Österreichischen Akademie der Wissenschaften in Wien, Serie A: Physische Anthropologie, XII.

Passmore R, Eastwood MA. 1986. Davidson and Passmore Human Nutrition and Dietetics, 8th edn. Longman Group Ltd.: Edinburgh, London, Melbourne and New York.

Patrick MK. 1989. An archaeological, anthropological study of the skeletal remains from the Oakhurst Rockshelter, George, Cape Province, South Africa. MA thesis, University of Cape Town.

Patriquin ML, Loth SR, Steyn M. 2003. Sexual dimorphic pelvic morphology in South African Whites and Blacks. HOMO 53(3): 255-262.

Penn N. 2005. The Forgotten Frontier: Colonist and Khoisan on the Cape's Northern Frontier in the 18th Century. Double Storey Books: Cape Town.

Pfeiffer S. 2007. The health of foragers: People of the Later Stone Age, southern Africa. Ancient Health: Skeletal Indicators of Agricultural and Economic Intensification, M Cohen, G Crane-Kramer (eds). University Press of Florida: Gainesville; 223-236.

Pfeiffer S. 2012. Conditions for evolution of small adult body size in southern Africa. Current Anthropology 53(S6): 383-394.

Pfeiffer S, Crowder C. 2004. An ill child among mid-Holocene foragers of southern Africa. American Journal of Physical Anthropology 123(1): 23-29.

Pfeiffer S, Harrington L. 2010. Child growth among southern African foragers. Human Diet and Nutrition in Biocultural Perspective, T Moffat, T Prowse (eds). Studies of the Biosocial Society, Vol. 5, Berghahn: Oxford; 35-56.

Pfeiffer S, Harrington L. 2011. Bioarchaeological evidence for the small adult stature in southern Africa: Growth, mortality and small stature. Current Anthropology 52(3): 449-461.

Pfeiffer S, Sealy J. 2006. Body size among Holocene foragers of the Cape Ecozone, Southern Africa. American Journal of Physical Anthropology 129: 1-11.

Powell ML. 1988. Status and Health in Prehistory. Smithsonian Institution Press: Washington, DC.

Rasool MN, Govender S. 1989. The skeletal manifestations of congenital syphilis. The Journal of Bone and Joint Surgery 71-B: 752-755.

Roberts CA, Buikstra JE. 2003. Bioarchaeology of Tuberculosis: A Global View on a Reemerging Disease. University of Florida Press: Gainesville.

Roberts C, Manchester K. 1995. The Archaeology of Disease, 2nd edn. Cornell University Press: Ithaca. 
Roberts C, Lucy D, Manchester K. 1994. Inflammatory lesions of ribs: an analysis of the Terry Collection. American Journal of Physical Anthropology 95: 169-182.

Rothschild BM, Rothschild C. 1996. Treponemal disease in the New World. Current Anthropology 37: 555-561.

Santos AL, Roberts CA. 2001. A picture of tuberculosis in young Portuguese people in the early 20th century: a multidisciplinary study of the skeletal and historical evidence. American Journal of Physical Anthropology 115: 38-49.

Sauer NJ. 1998. The timing of injuries and manner of death: Distinguishing among antemortem, perimortem and postmortem trauma. Forensic Osteology: Advances in the Identification of Human Remains, KJ Reichs (ed.). CC Thomas: Springfield, IL; 321-332.

Schoeman K. 2009. Seven Khoi Lives: Cape Biographies of the Seventeenth Century. Protea Book House: Pretoria.

Segen J. 2005. Concise Dictionary of Modern Medicine. Australia: McGraw-Hill Companies.

Silberbauer GB. 1965. Report to the Government of Bechuanaland on the Bushmen Survey. Bechuanaland Press: Mafikeng.

Smith A, Malherbe C, Guenther M, Berens P. 2000. The Bushmen of Southern Africa: A Foraging Society in Transition. David Philip: Cape Town.

Soames JV, Southam JC. 1993. Oral Pathology, 2nd edn. Oxford University Press: Oxford.

Steinbock RT. 1976. Paleopathological Diagnosis and Interpretation: Bone Diseases in Ancient Human Populations. Springfield, Illinois: Charles C. Thomas.

Steyn M. 1994. An assessment of the health status and physical characteristics of the prehistoric population from Mapungubwe. Ph.D., University of the Witwatersrand.

Steyn M, Işcan MY. 1999. Osteometric variation in the humerus: Sexual dimorphism in South Africans. Forensic Science International 106: 77-85.

Steyn M, Meiring JH, Nienaber WC, Loots M. 2002a. Large fontanelles in an early 20th century rural population from South Africa. International Journal of Osteoarchaeology 12: 291-296.

Steyn M, Nienaber WC, Meiring JH. 2002b. An assessment of the health status and physical characteristics of an early 20th century community at Maroelabult in the North West Province, South Africa. HOMO 53(2): 131-145.

Tanaka J. 1976. Subsistence ecology of central Kalahari San. Kalahari Hunter-Gatherers: Studies of the !Kung San and Their Neighbors, RB Lee, I DeVore (eds). Harvard University Press: Cambridge, Massachusetts and London; 98-119.

Tanaka J. 1980. The San: Hunter-Gatherers of the Kalahari. University of Tokyo Press: Tokyo.

Theal GM. 1905. Records of the Cape Colony: From December 1827 to April 1831, Vol. XXXV. William Clowes and Sons: London. 
Tobias PV. 1959. The Nuffield-Witwatersrand University expeditions to Kalahari Bushmen, 19581959. Nature 183: 1011-1013.

Tobias PV. 1961. Physique of a desert folk: Genes, not habitat, shaped the Bushmen. Natural History 170(2): 16-24.

Tobias PV. 1962. On the increasing stature of the Bushmen. Anthropos 57: 801-810.

Toohey JS. 1985. Skeletal presentation of congenital syphilis: A case report and review of the literature. Journal of Paediatric Orthopaedics 5: 104-106.

Torres-Rouff C, Costa Junqueira MA. 2006. Interpersonal violence in prehistoric San Pedro de Atacama, Chile: Behavioural implications of environmental stress. American Journal of Physical Anthropology 130: 60-70.

Truswell AS, Hansen JDL. 1976. Medical research among the !Kung. Kalahari Hunter-Gatherers: Studies of the !Kung San and Their Neighbors, RB Lee, I DeVore (eds). Harvard University Press: Cambridge, Massachusetts and London; 166-194.

Ubelaker D, Adams BJ. 1995. Differentiation of perimortem and postmortem trauma using taphonomic indicators. Journal of Forensic Sciences 40: 509-512.

Van der Merwe AE. 2006. Human skeletal remains from Kimberley: An assessment of health in a 19th century mining community. Unpublished MSc thesis, University of Pretoria.

Waldron T. 2009. Palaeopathology. Cambridge University Press: Cambridge.

Walker PL. 2001. A bioarchaeological perspective on the history of violence. Annual Review of Anthropology 30: 573-596.

Wood JW, Milner GR, Harpending HC, Weiss KM. 1992. The osteological paradox: Problems of inferring prehistoric health from skeletal samples. Current Anthropology 33(4): 343-370. 